\title{
Study of the mayfly order Ephemeroptera (Insecta) in Brazil: a scienciometric review
}

\author{
Yulie Shimano ${ }^{1}$, Frederico F. Salles ${ }^{2} \&$ Leandro Juen ${ }^{3}$
}

\begin{abstract}
'Programa de Pós-Graduação em Zoologia, Universidade Federal do Pará, Rua Augusto Correia, nº 1 Bairro Guamá, 66075-110 Belém-PA, Brazil. shimano.yulie@gmail.com

${ }^{2}$ Departamento de Ciências Agrárias e Biológicas, Universidade Federal de Espírito Santo, Centro Universitário Norte do Espírito Santo, Rodovia BR 101 Norte, Km 60, Bairro Litorâneo, 29932-540 São Mateus-ES, Brazil. ffsalles@gmail.com

${ }^{3}$ Instituto de Ciências Biológicas, Universidade Federal do Pará, Rua Augusto Correia, no 1 Bairro Guamá, 66075-110 Belém-PA, Brazil. leandrojuen@ufpa.br
\end{abstract}

\begin{abstract}
Study of the mayfly order Ephemeroptera (Insecta) in Brazil: a scienciometric review. Despite an increase in the number of studies in recent years of the aquatic insect order Ephemeroptera (the mayflies) much still remains to be learnt. In order to identify the current state of knowledge of this group in Brazil, we performed a scienciometric analysis with the purpose of identifying the strong and weak points of Brazilian research into the group. Our research used the "Institute for Scientific Information - ISI" database and was based on the abstracts, titles and keywords of manuscripts published between 1992 and 2011. We selected the papers with the combination of the words "Ephemeroptera" and "Brazil*" based on a search in February 2012. We analyzed 92 articles, and noted a lack of studies in some Brazilian states, no specific studies about some families, and an absence of phylogenetic studies. To improve ecological studies, it is necessary to fine-tune taxonomic resolution. Moreover, there is a lack of studies investigating the environmental variables which influence the distribution of mayflies. Despite these gaps, if the rate of publication with mayflies proceeds at the same pace, we anticipate that many of these knowledge gaps will be closed.
\end{abstract}

KEYWORDS. Biogeographic database; citation analyses; knowledge gaps; knowledge states; sampling effort.

The interest in the study of aquatic insects started in the 1930 s and 1940s because of studies with sport fishing interests (Merritt et al. 2008). Nowadays, these aquatic insects have become one of the groups most utilized in aquatic ecosystem and ecology research, often as water quality bio-indicators (e.g. Cummins 1973; Vison \& Hawkins 1998; Voelz \& McArthur 2000; Melo 2009; Dias-Silva et al. 2010; Juen \& De Marco 2011; Couceiro et al. 2012; Monteiro-Júnior et al. 2013).

One of the most important insect orders in aquatic ecosystems is the Ephemeroptera-the mayflies. These insects spend most of their life as immatures in water and emerge only to copulate and disperse; living first as subimagos, then imagos for a brief period, just two or three days in most of the species (Edmunds et al. 1976). The order is notable for including members in all functional feeding groups, and by being abundant and inhabiting most aquatic freshwater regions (Barber-James et al. 2008). The interest in studying the potential of mayfly nymphs as biologic indicators has increased in recent years. Following the accumulation of organic pollutants in streams and lakes there are concurrent changes in their abundance, sometimes resulting in local extinction (Da-Silva \& Salles 2012).

The first comprehensive study concerning mayflies in the Neotropical realm was published in 1924 (Needham \& Murphy 1924). Almost 100 years have passed and the taxonomy of the group is still considered poorly-known in Brazil (Da-Silva \& Salles 2012). According to Hubbard (1982), until the referred year, no general catalog of Ephemeroptera was published for the region. Recently, however, it has been possible to observe a progress in the study of this order in Brazil following the growing number of publications (e.g. Brito et al. 2011; Gonçalves et al. 2011a; Gonçalves et al. 2011b; Lima et al. 2011; Mariano 2011; Molineri et al. 2011; Salles \& Lima 2011; Souto et al. 2011; Boldrini et al. 2012; Couceiro et al. 2012).

Our goal was to carry out a scienciometric analysis of the order Ephemeroptera in Brazil. We aim to answer the following questions: (i) What is the rate of growth in scientific production with Ephemeroptera in recent years in Brazil? (ii) Are these papers being cited by others authors? (iii) In which regions and states of Brazil are these studies being carried out? (iv) In which journals are these studies being published? (v) Which are the most studied groups in Brazil? (vi) Which are the main characteristics and gaps in scientific production, taxonomic resolution, study type and life stage? Through this research it will be possible to identify the main knowledge gaps in the current literature of Brazilian mayflies once most part of knowledge will be summarize in this manuscript. By pointing the gaps, we hope to call attention to what remains to be done and studied within the order, encouraging new researches in poorly known areas.

\section{MATERIAL AND METHODS}

Our bibliographic research was carried out through the database of the "Institute for Scientific Information - ISI" (http://portal.isiknowledge.com). The research was based on 
the abstracts, titles and keywords of papers published between 1992 and 2011. Papers presenting the combination of words "Ephemeroptera" and "Brazil"" were selected.

To answer our questions, we analyzed information about the year of publication, the number of citations per year, journal, region and state where mayflies were sampled and the taxa studied in each paper. Papers involving more than one geographic region were counted once only for each region or state. Taxonomic groups were divided into three classes: Ephemeroptera (papers dealing with just one taxon inside the order), other groups (papers with groups cited like "macroinvertebrates", "benthos", "Insecta", "aquatic insects" or "aquatic invertebrates") and EPTs (papers dealing with the entire local community of Ephemeroptera, or Ephemeroptera and Trichoptera, or Ephemeroptera, Plecoptera and Trichoptera).

For information about taxonomic resolution, type of study and life stage, the following categories were used: (1) Taxonomic resolution. "Species", "morphospecies", "genus" or "family". When this information was not found in the abstract, we consulted the main body of the paper. When more than one resolution was used in the same article, we considered resolution applied for more than $50 \%$ of the identified taxa. (2) Study type. "Ecological with field approach", "ecological with experimental/observational approach", "taxonomical", "phylogenetic" or "species lists". We considered field approaches when the paper utilized a systematic methodology resulting in standardized and independent samples. We considered differences in experimental/observational approaches where results were either conducted in the laboratory or by direct observation (field or laboratory). "Taxonomical" were those papers that present species description or redescription, taxonomic recombination or identification keys. "Phylogenetic" were ones that presented character matrices and phylogenetic analyses. Finally, "species lists" were considered when the paper presented species lists or when only new records were reported. Papers that encompassed more than one category counted for more than one category (example: papers of species description accompanied by a phylogenetic analysis). (3) Life stage. "Nymph", "imago" or "both".

\section{RESULTS AND DISCUSSION}

We found 114 papers concerning the Ephemeroptera in Brazil. Five of them, however, were carried out by Brazilian authors, but not in Brazil, three did not focus on Ephemeroptera as the study group, and 14 dealt with stomach contents of fish (of which mayflies were found in their diet). These papers were removed from the analysis, and 92 papers remained to be analyzed. Although recognizing that our research method left out non-indexed papers, we believe that the standardization of the research is valid for our aim. In case of adopting a manual search to add information, we could inadvertently insert gaps in our results by adding non-indexed papers or by inserting papers that have not been reviewed by qualified referees. Using only papers within the ISI database, we ensure that all papers analyzed have been carefully reviewed. There are many examples of previous papers using only data from the ISI database (e.g. Melo et al. 2006; Carneiro et al. 2008; Padial et al. 2010; Thomaz et al. 2010).

Between 1992 and 2011, in four different years in the decade of the 1990s (1993, 1994, 1995 and 1998) there were no papers published on mayflies in Brazil (Fig. 1). After 2008, there was a rapid increase in the number of publications, and 2011 was the most productive year, with 23 published papers. More than one third of the papers were published in the last two years (36 papers). This tendency is concurrent with the increase of scientific papers of aquatic macrophytes in the Neotropics (Padial et al. 2008) and with international journals on limnology (Melo et al. 2006). A reason for the ascendant interest in aquatic insects can be related to the use of these orders as water bioindicators, as argued by Rosenberg \& Resh (1993), Hynes (1984), Merritt et al. (1984) and Resh \& Rosenberg (1984), as well as an increased interest in stream ecology (Allan 1995).

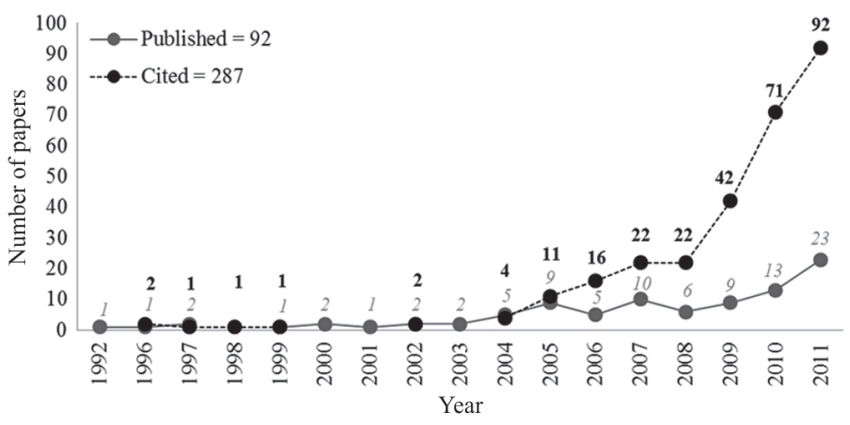

Fig. 1. Number of papers with the order Ephemeroptera (Insecta) published and cited in Brazil, between 1992 and 2011. Bold numbers above represent cited papers and italic numbers below represent published ones.

The 92 published papers were cited 287 times (Fig. 1), of which the most cited was Buss et al. (2002), cited 35 times, followed by Melo (2005) (cited 23 times) and Moulton et al. (2004) (cited 22 times). These three papers have an ecological approach. The first one investigated the influence of environmental factors on the macroinvertebrate fauna, the second one, on the impact of changes in taxonomic resolution on spatial patterns of macroinvertebrates and the third one investigated the relation between mayfly and shrimp communities and periphyton and sediment. It is clear that ecological papers are most cited than others. Thirty of the 92 studied papers were not cited at all, and the remaining papers were cited one (18 papers), two (11 papers), three (nine papers), four (seven papers), five (two papers), six (four papers), seven (three papers), eight (two papers) and 12, 14, $15,22,23$ and 35 times (one paper each of them). This is the general pattern of the distribution of citations for scientific papers as proposed by Padial et al. (2010), in which few papers receive a high number of citations, whereas most articles receive few or no citations at all. 
When we analyzed the regions in which the studies were conducted (Fig. 2), southeastern Brazil was the most studied, with more than $50 \%$ of the Brazilian publications (48) and Rio de Janeiro was the most-studied state, largely the result of the researchers J. Nessimian and E. Da-Silva. In the northern region, the laboratory coordinated by N. Hamada in Amazonas state occupied the second place in the publication rank. The high number of publications in Amazonas is also a result of the partnership accomplished by research groups led by N. Hamada and F. F. Salles. Ten of the 15 published papers incorporating data from the Amazon basin were made in association with these specialists. The large amount of work performed in the other northern states is reflective of the new researchers' formation by the Instituto de Pesquisa da Amazonia - INPA, that is currently working in Roraima and Amazonas.

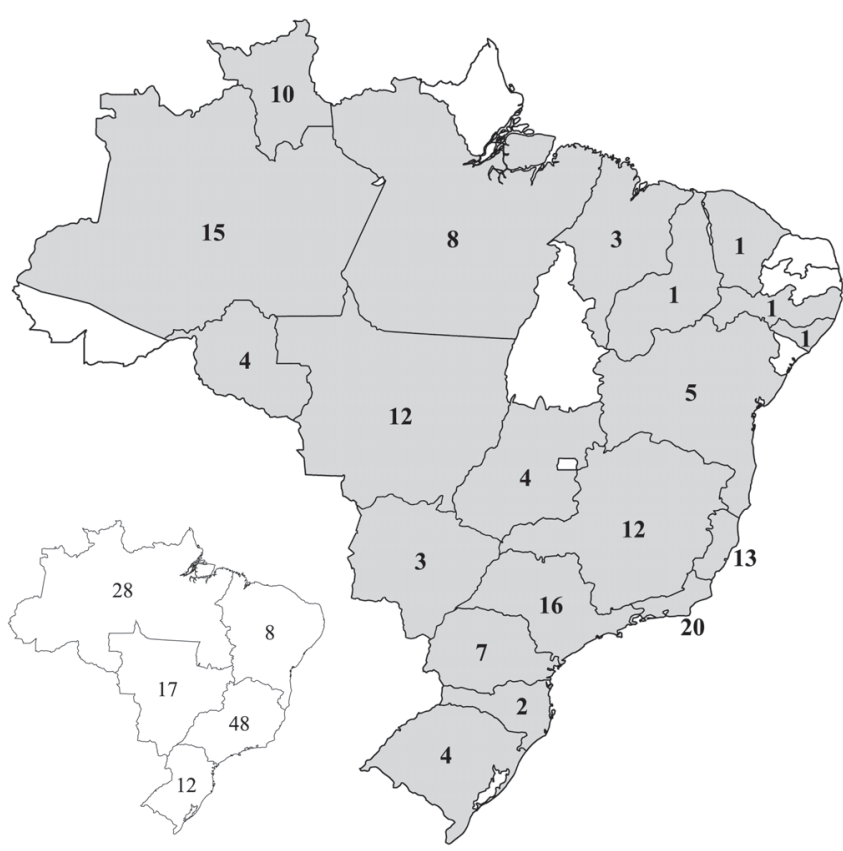

Fig. 2. Number of papers published with the order Ephemeroptera (Insecta) in Brazilian regions (below left) and in the Brazilian States, between 1992 and 2011. White states do not have published papers.

The northeast region is the least studied. Less than $10 \%$ of the papers published in Brazil were with mayflies sampled in this region, and three of the nine states still did not have any work up to the date of our search (Rio Grande do Norte, Paraíba and Sergipe). We also found a lack of knowledge in the northern region, with three states without published papers (Acre, Amapá and Tocantins), despite being the region with the second highest number of papers, as noted by Salles et al. (2004). In the midwest region we could not find studies carried out in the Distrito Federal.

The 92 papers were published in 23 journals. The most used journals were Zootaxa, Aquatic Insects and Annales de Limnologie (all non-Brazilian journals, Fig. 3). The first one focus on systematics papers, the second one, on systematics and ecology papers with aquatic insects, and the last one, only on ecology papers. Among the Brazilian journals, the most frequently used were Revista Brasileira de Zoologia (currently Zoologia), Revista Brasileira de Entomologia and Iheringia Série Zoologia. All of them publish in both systematics and ecology.

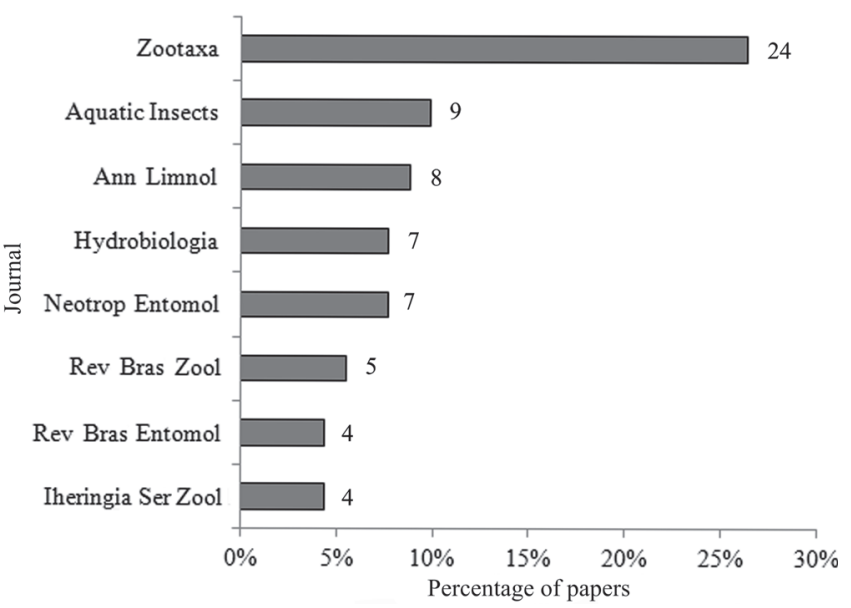

Fig. 3. Percentage and number of published papers in each of the most popular periodicals with the order Ephemeroptera (Insecta) in Brazil, between 1992 and 2011.

When we analyzed the taxonomic groups, 64 papers (more than $70 \%$ ) dealt exclusively with a single family of Ephemeroptera, 17 papers comprised Ephemeroptera, Plecoptera and Trichoptera (EPT) and 11 papers dealt with others groups too. The papers dealing with more than one family, in general, were ecology papers or species lists. Only five of the ten families found in Brazil had at least one paper dedicated to them (Fig. 4A). Our results show that Caenidae, Coryphoridae, Euthyplociidae, Ephemeridae and Melanemerellidae did not have a single paper dealing specifically with them, being only mentioned in species checklists. However, we are aware of a paper that cover one of these families in Brazil, Molineri \& Domínguez (2003), that were not included in the ISI results. It must be also pointed that Coryphoridae and Melanemerellidae are monotypic, minimizing the possibility of taxonomic papers being carried out. Euthyplociidae and Ephemeridae, in spite of being non-monotypic, have a low diversity in South America (Domínguez et al. 2006). Euthyplociidae has four recorded species to Brazil and Ephemeridae just one (Salles et al. 2012). Finally, Caenidae is little studied in Brazil with respect to taxonomy as well as to ecology. In Brazil, 12 of the 19 recorded species have been cited only in the paper containing their respective original description (see http://ephemeroptera.com.br).

Baetidae, on the other hand, was the most studied family, with almost $45 \%$ of the papers (27). Probably, the available resources allowing for identification at the larval stage of this family have contributed to this result once the knowl- 


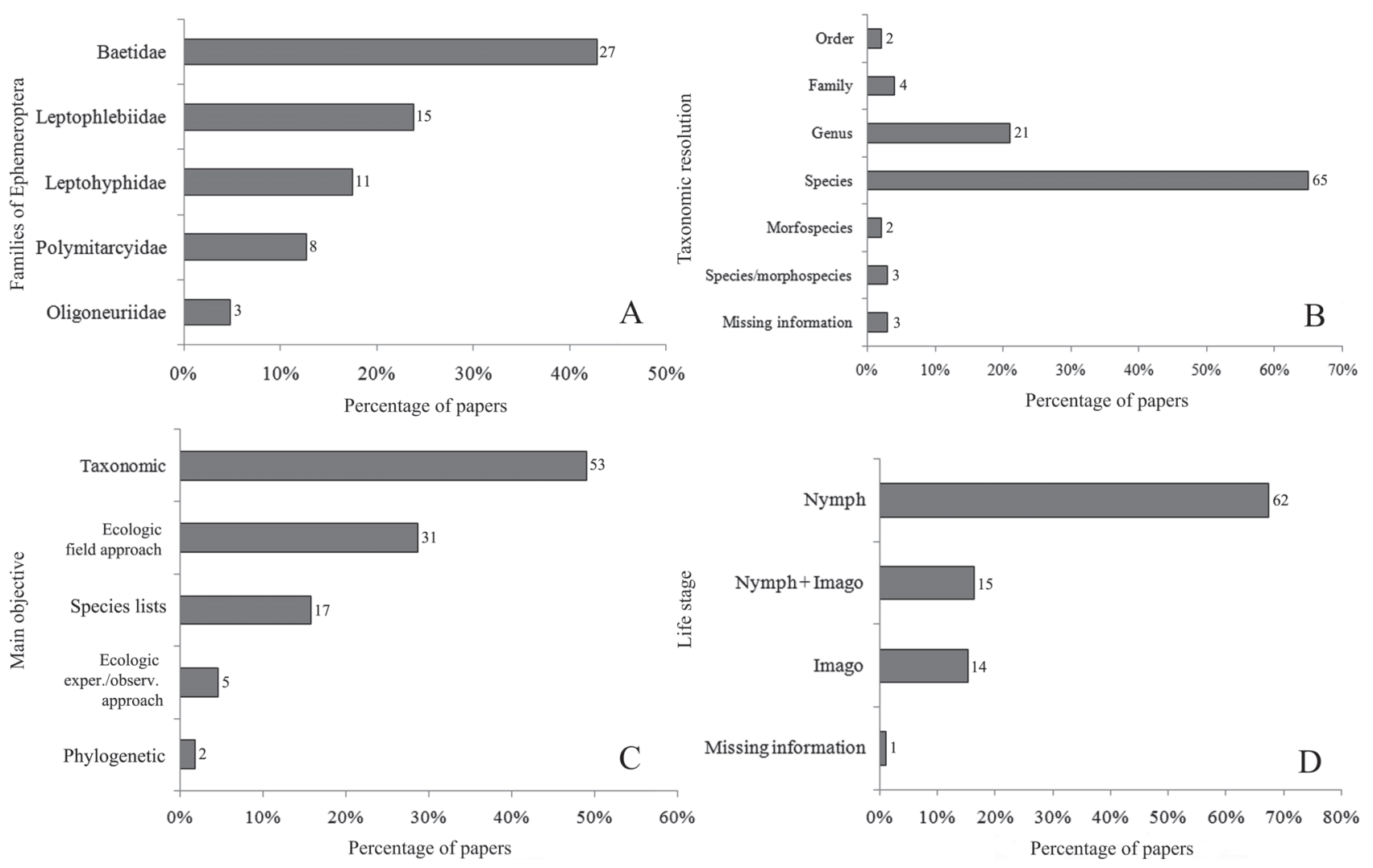

Fig. 4. Percentage and number of published papers according to: Ephemeroptera families (A); taxonomic resolution (B); main objective (C) and life stage of mayflies (D), between the years 1992 and 2011.

edge regarding nymphal stage characters useful for identifying genera and species of Baetidae has increased substantially (Waltz \& Burian, 2008). Also, the high diversity of the taxon (83 species recorded from Brazil in Salles et al. 2012) may have contributed almost $50 \%$ of papers about Ephemeroptera. Another important factor is the high quantity of specialist researchers working on Baetidae, at least five nowadays (employed specialists plus doctoral students).

We believe that the five most studied families provide representative ecological data for the order since all functional feeding groups are found in these families (Shimano et al. 2012). Gathering-collectors are represented by Baetidae, Euthyplociidae and Leptohyphidae, filtering-collectors by Oligoneuriidae and Leptophlebiidae, predators by Baetidae, scrapers by Baetidae and Leptophlebiidae, and finally, shredders by Leptophlebiidae.

Most papers (65\%) provided identifications at species level (Fig. 4B). The increase of studies with species-level identification is probably a consequence of the publication of an identification key for the Brazilian mayflies (Salles 2006) and of the book "Ephemeroptera of South America" (Domínguez et al. 2006). Salles' (2006) identification key has images of relevant body structures, allowing for reliable genus-level identification, and therefore making species identification possible. Domínguez et al. (2006), in turn, offers species keys for most South American taxa. Furthermore, there has been more papers dealing with taxonomy, there- fore reflecting in more papers with species level identifications. According to Merritt et al. (2008), identification at the species level is important in ecological studies as congeneric species do not necessarily have the same ecological requirements or identical water quality tolerance.

Considering the type of study, almost $50 \%$ of the papers are species descriptions or identification keys (Fig. 4C). There is also a considerable amount of papers dealing with the ecology of Ephemeroptera $(31 ; 30 \%)$, but most were conducted together with others orders (Trichoptera and Plecoptera), aquatic insects or even with macroinvertebrates in general. Only one ecological paper evaluated the environmental influence on the Ephemeroptera community (Buss et al. 2002). According to Buss et al. (2002), Riparian Channel Environment index, dissolved oxygen and dissolved chloride were acting on Ephemeroptera communities together with those of other macroinvertebrates.

The review papers, those including species lists and new or additional records, also represent a considerable percentage of studies (17\%). The first list of Brazilian mayfly species (Salles et al. 2004) reported 10 families, 63 genera and 166 species. Today, 10 families, 68 genera and 233 species have been recorded (Salles et al. 2012). Even so, according to Da-Silva \& Salles (2012) it is assumed that twice as many species still remain to be described or recorded in Brazil. A large current gap is found in the study of Ephemeroptera systematics (only $2 \%$ of the papers), with only two papers 
published in the studied period (Nieto \& Salles 2006; Salles et al. 2009).

The majority of the papers (almost $70 \%$ ) studied nymphs (Fig. 4D). According to Waltz \& Burian (2008), the major part of taxonomical and ecological papers with Ephemeroptera is focused on nymphs because of the brief adult life and their limited activity. Moreover, in ecological cases, nymphs are much more important due their role in aquatic nutrient cycle (Cummins et al. 2008). Only one ecological paper dealt with imagoes, but, mayflies were identified at the order level (Silva et al. 2011). The high number of taxonomic papers dealing with nymphs is probably due to the paucity of information in old descriptions (sometimes only a single paragraph). One way to solve part of the taxonomic uncertainties for aquatic insects is through the association between nymphs and imagoes (Merritt et al. 2008), what is reflected in the higher percentage of studies dealing with nymph-imago associations $(16.3 \%)$ compared to the percentage of studies involving only imagoes (15.2\%). In addition, apparently, nymphs are easier to sample than imagoes, and require less financial resources.

Concluding, the main gaps found with research on Ephemeroptera in Brazil are: (1) a lack of mayflies studies in some Brazilian states (Rio Grande do Norte, Paraíba, Sergipe, Acre, Amapá, Tocantins and the Distrito Federal), (2) absence of specific studies with some families in Brazil, such as: Caenidae, Coryphoridae, Euthyplociidae, Ephemeridae and Melanemerellidae, (3) absence of studies dealing with phylogenetic relationships, (4) need for improvement of the taxonomic resolution in ecological studies, especially when considering future conservation actions, and (5) lack of knowledge about the environmental variables which may be affecting the distribution of these organisms.

\section{ACKNOWLEDGMENTS}

We would like to express our gratitude to Andre Padial for reviewing an early draft of this manuscript and to Alexander C. Lees for the English review. Y. Shimano is grateful to Fundação Amazônia Paraense for a scholarship.

\section{REFERENCES}

Allan, J.D., 1995. Stream ecology: structure and function of running waters. London, Chapman \& Hall, 388 p.

Barber-James, H.M., Gattolliat, J.-L., Sartori, M. \& Hubbard, M.D. 2008. Global diversity of mayflies (Ephemeroptera, Insecta) in freshwater. Hydrobiologia 595: 339-350.

Boldrini, R., Cruz, P.V., Salles, F.F., Belmont, E.L. \& Hamada, N. 2012. Baetidae (Insecta: Ephemeroptera) from northeastern Brazil. Check List 8: 88-94.

Brito, P., Salles, F.F. \& Dolder, H. 2011. Characteristics of the male reproductive system and spermatozoa of Leptophlebiidae (Ephemeroptera). Neotropical Entomology 40: 103-107.

Buss, D.F., Baptista, D.F., Silveira, M.P., Nessimian, J.L. \& Dorvillé, L.F.M. 2002. Influence of water chemistry and environmental degradation on macroinvertebrate assemblages in a river basin in south-east Brazil. Hydrobiologia 481: 125-136.
Carneiro, F.M., Nabout, J.C. \& Bini, L.M. 2008. Trends in the scientific literature on phytoplankton. Limnology 9: 153-158.

Couceiro, S.R.M., Hamada, N., Forsberg, B.R., Pimentel, T.P. \& Luz, S.L.B. 2012. A macroinvertebrate multimetric index to evaluate the biological condition of streams in the Central Amazon region of Brazil. Ecological Indicators 18: 118-125.

Cummins, K.W. 1973. Trophic relations of aquatic insects. Annual Review of Entomology 18: 183-206.

Cummins, K.W., Merritt, R.W. \& Berg, M.B. 2008. Ecology and distribution of aquatic insects, p. 105-122. In: Merritt, R.W., Cummins, K.W. \& Berg, M.B. (eds.). An introduction to the aquatic insects of North America. Fourth edition, Dubuque, Kendall/Hunt Publishing Company, 1214 p.

Da-Silva, E.R. \& Salles, F.F. 2012. Ephemeroptera Hyatt \& Arms, 1891, p. 231-244. In: Rafael, J.A., Melo, G.A.R., Carvalho, C.J.B., Casari, S.A. \& Constantino, R. (eds.). Insetos do Brasil: Diversidade e taxonomia. Ribeirão Preto, Holos, 810 p.

Dias-Silva, K., Cabette, H.S.R., Juen, L. \& DeMarco, P. 2010. The influence of habitat integrity and physical-chemical water variables on the structure of aquatic and semi-aquatic Heteroptera. Zoologia 27: 918-930.

Domínguez, E., Molineri, C., Pescador, M.L., Hubbard, M.D. \& Nieto, C. 2006. Aquatic Biodiversity of Latin America. Vol. 2. Ephemeroptera of South America. Sofia, Pensoft, 646 p.

Edmunds Jr., G.E., Jensen, S.L. \& Berner, L. 1976. The Mayflies of North and Central America. Minnesota, University of Minnesota Press, $330 \mathrm{p}$.

Gonçalves, I.C., Cid, B., Mortati, A.F., Quesado, L.B. \& Nessimian, J.L. 2011a. Relative size of gills of Cloeodes jaragua Salles \& Lugo-Ortiz, 2003 (Ephemeroptera, Baetidae) on pool and riffle areas of streams at the Atlantic Rainforest. Biota Neotropica 11: 217-220.

Gonçalves, I.C., Da-Silva, E.R. \& Nessimian, J.L. 2011b. Oligoneuria macabaiba sp. nov. (Insecta: Ephemeroptera) from Brazil. Revista de Biologia Tropical 59: 1553-1557.

Hubbard, M.D. 1982. Catálogo abreviado de Ephemeroptera da América do Sul. Papéis Avulsos de Zoologia 34: 257-282.

Hynes, H.B.N. 1984. The relationships between the taxonomy and ecology of aquatic insects, p. 9-23. In: Resh, V.H. \& Rosenberg, D.M. (eds.). The Ecology of Aquatic Insects. New York, Praeger Publishers, 625 p.

Juen, L. \& DeMarco, P. 2011. Odonata biodiversity in terra-firme forest streamlets in Central Amazonia: on the relative effects of neutral and niche drivers at small geographical extents. Insect Conservation and Diversity 4: 265-274.

Lima, L.R.C., Salles, F.F. \& Pinheiro, U.S. 2011. New species of Leptohyphidae (Ephemeroptera) from northeastern Brazil. Zootaxa 3050: 63-68.

Mariano, R. 2011. A new species of Paramaka Savage \& Domínguez, 1992 (Ephemeroptera: Leptophlebiidae: Atalophlebiinae) from Brazil. Zootaxa 3038: 45-50.

Melo, A.S. 2005. Effects of taxonomic and numeric resolution on the ability to detect ecological patterns at a local scale using stream macroinvertebrates. Archiv für Hydrobiologie 164: 309-323.

Melo, A.S. 2009. Explaining dissimilarities in macroinvertebrate assemblages among stream sites using environmental variables. Zoologia 26: 79-84.

Melo, A.S., Bini, L.M. \& Carvalho, P. 2006. Brazilian articles in international journals on Limnology. Scientometrics 67: 187-199.

Merritt, R.W., Cummins, K.W. \& Burton, T.M. 1984. The role of aquatic insects in the processing and cycling of nutrients, p. 134-163. In: Resh, V.H. \& Rosenberg, D.M. (eds). The Ecology of Aquatic Insects. New York, Praeger Publishers, 625 p.

Merritt, R.W., Cummins, K.W. \& Berg, M.B. 2008. An introduction to the aquatic insects of North America. Dubuque, Kendall/Hunt Publishing Company, 1214 p.

Molineri, C. \& Domínguez, E. 2003. Nymph and egg of Melanemerella brasiliana (Ephemeroptera: Ephemerelloidea: Melanemerellidae), with comments on its systematic position and the higher classification of Ephemerelloidea. Journal of North American Benthological Society 22: $263-275$. 
Molineri, C., Cruz, P.V. \& Emmerich, D. 2011. A new species of Asthenopus (Ephemeroptera: Polymitarcyidae: Asthenopodinae) from Brazil and Colombia. Zootaxa 2750: 33-38.

Monteiro Júnior, C.S., Couceiro, S.R.M., Hamada, N. \& Juen, L. 2013. Effect of vegetation removal for road building on richness and composition of Odonata communities in Amazonia, Brazil. International Journal of Odonatology 16: 135-144.

Moulton, T.P., Souza, M.L., Silveira, R.M.L. \& Krsuloviæ, F.A.M. 2004. Effects of ephemeropterans and shrimps on periphyton and sediments in a coastal stream (Atlantic forest, Rio de Janeiro, Brazil). Journal of the North American Benthological Society 23: 868-881.

Needham, J.G. \& Murphy, H.E. 1924. Neotropical mayflies. Bulletin of the Lloyd Library of Botany, Pharmacy and Materia Medica 24 (Entomological Series 4): 1-79.

Nieto, C. \& Salles, F.F. 2006. Revision of the Genus Paracloeodes (Ephemeroptera: Baetidae) in South America. Zootaxa 1303: 1-33.

Padial, A.A., Nabout, J.C., Siqueira, T., Bini, L.M. \& Diniz-Filho, J.A.F. 2010. Weak evidence for determinants of citation frequency in ecological articles. Scientometrics 85: 1-12.

Padial, A.A., Bini, L.M. \& Thomaz, S.M. 2008. The study of aquatic macrophytes in Neotropics: a scientometrical view of the main trends and gaps. Brazilian Journal of Biology 68: 1051-1059.

Resh, V.H. \& Rosenberg, D.M. 1984. The Ecology of Aquatic Insects. New York, Praeger Publishers, 625 p.

Rosenberg, D.M. \& Resh, V.H. 1993. Introduction to freshwater biomonitoring and benthic macroinvertebrates, p. 1-9. In: Rosenberg, D.M. \& Resh, V.H. (eds.). Freshwater biomonitoring and benthic macroinvertebrates. New York, Chapman \& Hall, 488 p.

Salles, F.F. \& Lima, M.M. 2011. New species and new records of Miroculis Edmunds (Ephemeroptera: Leptophlebiidae) from Southeastern Brazil. Zootaxa 2740: 53-58.

Salles, F.F. 2006. A ordem Ephemeroptera no Brasil (Insecta): taxonomia e diversidade. $\mathrm{Ph}$. D. dissertation. Viçosa, Universidade
Federal de Viçosa, $300 \mathrm{p}$.

Salles, F.F., Francischetti, C.N. \& Soares, E.D.G. 2009. The presence of Homoeoneuria s.s. (Ephemeroptera: Oligoneuriidae) in South America with the description of a new species. Zootaxa 2146: 53-60.

Salles, F.F., Da-Silva, E.R., Hubbard, M.D. \& Serrão, J.E. 2004. As espécies de Ephemeroptera (Insecta) registradas para o Brasil. Biota Neotropica 4: 1-34.

Salles, F.F., Boldrini, R., Nascimento, J.C.M., Raimundi, E.A. \& Shimano, Y. 2012. Ephemeroptera do Brasil. Available at: https://sites.google.com/ site/ephemeropterabr (accessed 14 May 2012).

Shimano, Y., Salles, F.F., Faria, L.R.R., Cabette, H.S.R. \& Nogueira, D.S. 2012. Distribuição espacial das guildas tróficas e estruturação da comunidade de Ephemeroptera (Insecta) em córregos do Cerrado de Mato Grosso, Brasil. Iheringia, Série Zoologia, 102: 187-196.

Silva, N.A.P., Frizzas, M.R. \& Oliveira, C.M. 2011. Seasonality in insect abundance in the "Cerrado" of Goiás State, Brazil. Revista Brasileira de Entomologia 55: 79-87.

Souto, R.M.G., Facure, K.G., Pavanin, L.A. \& Jacobucci, G.B. 2011. Influence of environmental factors on benthic macroinvertebrate communities of urban streams in Vereda habitats, Central Brazil. Acta Limnologica Brasiliensia 23: 293-306.

Thomaz, S.M., Michelan, T.S., Carvalho, P. \& Bini, L.M. 2010. The influence of "Homage to Santa Rosalia" on aquatic ecology: a scientometric approach. Hydrobiologia 653: 7-13.

Vison, M.R. \& Hawkins, C.P. 1998. Biodiversity of stream insects: Variation at local, basin and regional scales. Annual Review of Entomology 43: 271-193.

Voelz, N.J. \& McArthur, J.V. 2000. An exploration of factors influencing lotic insect species richness. Biodiversity and Conservation 9: 1543-1570.

Waltz, R.D. \& Burian, S.K. 2008. Ephemeroptera, p. 181-236. In: Merritt, R.W., Cummins, K.W. \& Berg, M.B. (eds.). An introduction to the aquatic insects of North America. Dubuque, Kendall/Hunt Publishing Company, $1214 \mathrm{p}$.

Received 9 December 2012; accepted 4 November 2013

Associate Editor: Marcio R. Pie 